Е.А. Савина

ФГБОУ ВПО «МГСУ»

ИННОВАЦИОННАЯ ДЕЯТЕЛЬНОСТЬ

КАК УСЛОВИЕ РАЗВИТИЯ

ПРОФЕССИОНАЛЬНОЙ

НАПРАВЛЕННОСТИ ЛИЧНОСТИ

НАУЧНО-ПЕДАГОГИЧЕСКИХ

РАБОТНИКОВ ИНВЕСТИЦИОННОСТРОИТЕЛЬНОЙ СФЕРЫ

Представлены результаты изучения педагогической направленности научно-педагогических работников. Дано обоснование инновационной деятельности как оптимально развивающей педагогическую направленность личности. Сделан вывод, что для развития педагогической направленности научно-педагогических работников в условиях инновационной деятельности следует усилить инновационную среду.

Ключевые слова: педагогическая направленность, инновационная деятельность, условия развития, инновации в педагогике, развитие личности, инновационная среда.

Смена приоритетов в образовании, волна инноваций, охватившая все уровни и звенья системы образования, вызванная кардинальными изменениями социально-экономического уклада жизни россиян, требуют совершенно новых подходов в подготовке научно-педагогических кадров, которые будут способны на высоком педагогическом уровне решать проблемы профессионального образования.

Профессиональная сфера деятельности человека носит сугубо избирательный характер, поэтому появляется необходимость выделять, формировать и развивать ключевые личностные качества и ориентировать их на выполнение ведущих социальных и профессиональных функций. Поэтому развитие направленности личности педагогических работников будет способствовать решению проблемы подготовки качественных специалистов в образовании. Нельзя не согласиться со В.А. Сластениным, считавшим, что «одной из проблем образования является повышение уровня профессиональной направленности учителя» [1].

Педагогическая направленность как качество личности важна и для научнопедагогических работников, от уровня профессиональной деятельности которых напрямую зависит качество образования и формирования личности специалиста.

\section{E.A. Savina \\ MGSU \\ INNOVATIVE ACTIVITY \\ AS A DEVELOPMENT CONDITION FOR PROFESSIONAL \\ ORIENTATION OF A PERSONALITY \\ OF ACADEMIC EMPLOYEE \\ IN INVESTMENT \\ AND CONSTRUCTION SPHERE}

The article presents the results of educational orientation of academic staff investigation. The author gives substantiation of innovative activity as optimally developing the pedagogic orientation of a personality. The conclusion is made that in order to develop the pedagogic orientation of academic staff in the conditions of innovative activity it is necessary to strengthen the innovative environment.

Key words: pedagogic orientation, innovative activity, development conditions, innovations in education, personality development, innovative environment.

The changing priorities in the education, a stream of innovations, which involved all the levels and branches of the system of education, which was caused by fundamental changes in social and economic order of the life of the Russians, require absolutely new approaches to education of academic staff, which will be able to solve the problems of professional education on high pedagogical level.

The professional sphere of a human is of purely selective character, that's why appears the necessity to detach, form and develop the key personality qualities and orient them on fulfilling the leading social and professional functions. That's why the development of personality orientation of academic staff will. We cannot disagree with V.A. Slastenin, who believed that "one of the problems of education is raising the level of professional orientation of a teacher" [1].

Pedagogic orientation as personality quality is important for academic staff, because the quality of education and professional personality formation depends on his or her professional activity.

The development of the professional orientation of a personality depends on the 
Развитие профессиональной направленности личности зависит от понимания различных подходов к составляющим структуры направленности личности, общетеоретической концепции личности, от понимания условий и факторов ее формирования [2].

Изучение теории и практики развития профессиональной направленности, в т.ч. и педагогической, позволяет сделать выводы:

в современный период для развития образования и общества профессиональная направленность имеет большое значение, так как от ее сформированности зависит реализация способностей человека;

определение понятия «профессиональнопедагогическая направленность» дают многие авторы, но эти различные представления объединяет то, что профессионально-педагогическая направленность понимается как стремление в овладении определенной профессией через отношение, готовность, мотивы;

компоненты структуры педагогической направленности рассматриваются как: мотивация к учению, отношение к профессии, в т.ч. и педагогической, система мотивов выбора педагогической профессии;

смысл жизни и профессиональное самоопределение выражают общая и профессиональная направленности личности [3].

В научно-педагогической литературе выделены условия развития профессиональной и педагогической направленности:

профессиональный отбор, ведущая профессиональная деятельность, профессиональная самооценка;

общественные отношения, социальные ожидания, специально организованное образование, активация профессионального самообразования и самовоспитания;

совершенствование профессиональной деятельности и педагогического процесса, направленность деятельности педагогов на организацию учебно-педагогической развивающей деятельности обучаемых в еe многообразных формах;

интеграция общенаучных, психологопедагогических и специальных дисциплин [3].

Так как профессиональная направленность обосновывается широким набором потребностей, интересов, идеалов, установок человека, то выбираемая деятельность должна предоставить условие для их формирования. Нельзя не согла- understanding of different approaches to the components of personality orientation structure, general theoretic concept of a personality, from the understanding of the conditions and factors of its formation [2].

The studying of the theory and practice of professional orientation development, which includes pedagogical, helps to make the following conclusions:

in the contemporary period of education and society development the professional orientation is of great importance, because the fulfillment of human capabilities depends on its formedness;

the definition of the notion "professional pedagogic orientation" is offered by many authors, but these different opinions are united by the fact that professional pedagogic activity is understood as a wish to master a certain profession with the help of attitude, readiness, motives;

the components of pedagogical orientation structure are considered as: motivation to learning, attitude towards the profession, which includes the pedagogical one, the system of choosing the motives for pedagogic profession;

the purpose of life and professional identity are expressed by general and professional orientation of a personality [3].

In scientific pedagogical literature the conditions for professional and pedagogical orientation development are emphasized:

professional selection, leading professional activity, professional self estimation;

public relations, social expectations, specially organized education, activation of professional self-education and selfimprovement;

advancement of professional activity and pedagogic process, orientation of the teaching staff on the organization of educational activity of students in its various forms;

integration of general scientific, psychological, pedagogical and special diciplines [3].

As far as professional orientation is based on the wide range of requirements, interests, ideals, affirmations of a person, the chosen activity should give the condition for their formation. We can't disagree 
ситься с Б.М. Тепловым, считавшим, что индивидуальные психологические особенности не только проявляются в деятельности, но и создаются в ней.

Интенсивное развитие профессиональнопедагогической направленности личности, в т.ч. и научно-педагогического работника, происходит при наличии особых специальных условий, воплощение этих условий осуществляется в системе образовательного процесса учебного учреждения.

Проблемы влияния на педагогическую направленность личности специальных условий, отражающих активную деятельность, включая педагогическую, описаны в научной литературе. Развитие и активность личности зависит от многих факторов, в т.ч. и от уровня профессионального мастерства учителя. В.А. Сластенин считает его высшей формой профессиональнопедагогической направленности. Однако исследования изменения в профессиональной направленности научно-педагогических работников, содержанием условий развития которой является инновационная деятельность, отсутствуют в научной литературе, что обусловливает новизну и актуальность данного исследования $[1,3]$.

Под инновационной деятельностью следует понимать выполнение работ и (или) оказание услуг, направленных на создание и организацию производства принципиально новой или с новыми потребительскими свойствами продукции (товаров, работ, услуг); создание и применение новых или модернизацию существующих способов (технологий) ее производства, распространения и использования; применение структурных, финансово-экономических, кадровых, информационных и иных инноваций (нововведений) при выпуске и сбыте продукции (товаров, работ, услуг), обеспечивающих экономию затрат или создающих условия для такой экономии [4].

Другое понятие - инновационная деятельность - это комплекс принимаемых мер по обеспечению инновационного процесса на том или ином уровне образования, а также сам процесс [5].

Проблема исследования инновационной деятельности как условия развития педагогической направленности научно-педагогических работников обусловлена противоречиями:

между необходимостью развития педагогической направленности научно-педагогических работников в условиях инновационной педагоги- with B.M. Teplov, who thought that individual psychological peculiarities are expressed not only in the activity, but are also created in it.

The intensive development of professional pedagogic orientation of a personality, which includes the personality of an academic employee, happens in the presence of special conditions, the implementation of these conditions happens in the system of educational process of an educational institution.

The problems of the influence of special conditions on pedagogical orientation of a personality, which reflect a vigorous activity, including pedagogical, are described in the scientific literature.

The development and activity of a personality depends on many factors, which includes the level of the professional skills of a teacher. V.A. Slastenin believes it to be the utmost form of professional pedagogic orientation. Though there are no investigations of the changes in professional orientation of academic staff in scientific literature, the development condition of which is innovative activity. This fact determines the recency and urgency of the given investigation [1,3].

Under innovative activity we should understand execution of works or rendering services aimed at creation and organization of production of a brand new production or a production with new consumer performances (goods, works, services); creation and application of new or modernization of the existing ways (technologies) of its production, distribution and application; the use of structural, financial economic, employee, informational and other innovations (introductions) in the process of manufacturing and sale of the production (goods, works, services), which provide cost savings or create the conditions for such savings [4].

Another notion - innovative activity - is a complex of the measures taken to provide the innovative process on the given educational level, as well as the process itself [5].

The problem of innovative activity investigation as a condition for developing pedagogical orientation of the academic 
ческой деятельности и недостаточной подготовленностью вузов к инновационному обучению;

потребностью педагогической практики в осуществлении научно-педагогическими работниками инновационной деятельности и недостаточной сформированностью у них педагогической направленности.

В нашем исследовании не случаен выбор развития педагогической направленности у научно-педагогических работников, так как вхождение личности в профессиональную среду является важным этапом профессиональной направленности личности:

послевузовский этап формирования направленности, характеризуется развитием профессиональной направленности непосредственно в трудовой деятельности начинающего специалиста [6];

отдельные свойства (качества) личности, ее направленность изменяются в профессиональной среде, а взаимодействие профессиональной среды и личности, что является необходимым этапом в развитии личности как «субъекта социальных отношений»; что, в свою очередь, приводит к появлению в структуре личности новообразования профессиональной направленности;

преподаватель, выпускник технического вуза, «абсолютно не знающий теоретических основ преподавания и в большинстве случаев не имеющий практического преподавательского опыта» [7] вряд ли сумеет на достаточно высоком профессиональном уровне осуществлять образовательный процесс в вузах, не владеет необходимыми общими и профессиональными компетенциями для решения задач современного высшего профессионального образования вузов;

аспирант, работающий в качестве преподавателя, не подготовлен к педагогической деятельности;

М.В. Ломоносов впервые высказал мысль о содержании преподавательской и научной деятельности [7];

начинающий преподаватель технического вуза, не имея навыков педагогической деятельности, может годами эмпирическим путем идти к педагогическому мастерству, что не приносит, как показывает наука и практика, существенных результатов [8].

Определяя условия и факторы, влияющие на развитие профессиональной направленности научно-педагогических работников, мы исходим из полисистемного характера жизнедеятельно- staff is caused by the contradictions between them:

the necessity to develop pedagogic orientation of academic staff in the conditions of innovative pedagogic activity and lack of preparation of the universities to innovative education;

the need of pedagogical practice in innovation activity of academic staff and lack of pedagogic orientation formation in them.

In our investigation the choice of pedagogical orientation development on academic staff is not random, because the entrance of a person into professional environment is an important of professional orientation of a personality:

after university stage of orientation formation is characterized by the development of professional orientation exactly in working activity of a beginning specialist [6];

separate features (qualities) of a personality, its orientation are changing in professional environment, and the interaction of a professional environment and a personality, which is a necessary step in personality development as a "subject of social relations", which is leading to an innovation in personality structure - a professional orientation;

a lecturer, a graduate of a technical institute, who "absolutely doesn't know theoretic basis of teaching and in most cases doesn't have practical teaching experience" [7] wouldn't most likely realize the educational process on a high professional level in universities, he doesn't possess the necessary general and professional competences for solving the tasks of the contemporary higher professional education;

a postgraduate student working as a lecturer is not prepared to pedagogic activity;

M.V. Lomonosov was the first to express the opinion on the composition of teaching and scientific activity [7];

a starting teacher of a technical institute without the experience of pedagogic activity can empirically walk towards pedagogic skills for years, which, as science and practice show, doesn't show good results [8]. 
сти человеческой личности вообще и преподавателя в частности. «Позиция, занимаемая данным конкретным человеком в обществе (и его подсистемах), - подчеркивает Б.Ф. Ломов, - определяет направленность, содержание и способы его деятельности, а также сферу и способы общения этого человека с другими людьми, т.е. образ его жизни, как члена общества» [9].

Выбор инновационной деятельности как условия развития педагогической направленности личности, в т.ч. и научно-педагогических работников, опирается на исследования М.-Н. Томпсона, показывающие, что оптимизирует учебную деятельность и обучение, ориентированное на действие, приносит учащимся большое субъективное удовлетворение [3].

Обоснованием выбора инновационной деятельности как условия являются и научные исследования, показывающие:

что психологической основой развития профессиональной направленности является ведущая деятельность, которая по мере усложнения и развития усиливает направленность личности на будущую профессиональную деятельность [10], Поэтому нами была выбрана инновационная деятельность;

профессиональная направленность «характеризует готовность личности к конкретному виду трудовой деятельности и наличие склонностей к избираемой профессии, проявляющихся в так называемых ,первых трудовых пробах в облюбованных видах труда ${ }^{\text {‘е }) ~[11] ; ~}$

чем насыщеннее содержание профессиональной направленности, тем более осознанный смысл имеет для человека выбор конкретного вида деятельности, и тем полнее удовлетворение, которое он получает от воплощения данного намерения [12]. В инновационной педагогической деятельности проявляется профессионализм начинающего специалиста (способность рефлексировать, находить причину поступков, задавать себе вопросы, самостоятельно искать на них ответы) $[1,4]$;

инновации обладают большим системным влиянием на все компоненты педагогического процесса, на деятельность и общую структуру педагогического сообщества в целом [1];

педагоги, работающие в инновационной школе, обладают более широким спектром направленности - они стремятся к взаимодействию жизненных и профессиональных сфер, к свободе, готовы к новому, ориентированы на
Estimating the conditions and factors influencing the development of professional orientation of academic staff, we base on polysystemic character of a person activity in general and of a teacher in particular. "The position taken by a concrete person in the society (and its subsystems), — as B.F. Lomov emphasizes, - determines the orientation, content and ways of his or her activity, as well as the sphere and communication ways of this person with other people, which means the way of life as a member of the society" [9].

The choice of innovative activity as a condition for pedagogic orientation development of a person, which includes academic staff, is based on the investigations of M.-N. Thompson, which shows what optimizes the educational activity and education oriented at activity, brings the students great subjective satisfaction [3].

Also scientific investigations are the substantiation of the choice of innovative activity as a condition. They show that:

psychological basis for professional orientation development is a leading activity, which together with complication and development strengthens the orientation of a personality at future professional activity [10]. That's why we chose innovative activity;

professional orientation "characterize the preparation of a personality for a concrete type of working activity and presence of inclinations to the profession, which exhibits itself in "the first working experiences in the chosen types of work"' [11];

the richer is the content of professional orientation, the more conscious is the choice of the concrete activity type and the fuller is the satisfaction he receives from this intention implementation [12]. In innovative pedagogic activity manifests itself the professionalism of a starting specialist (ability to reflect, find a cause of actions, state questions to oneself, seek for the answers) $[1,4]$;

innovations have a great systematic influence on all the components of pedagogical process, on the activity and general structure of pedagogical society in general [1];

the teachers working in innovative school possess more wide range of orientation - they strive to interaction of life and 
высокий уровень достижения в профессиональной деятельности и его официальном признании. Характеризуются гибкостью, толерантностью, эмоциональной стабильностью, оптимизмом, эмпатией, аттракцией, развитым эмоциональным самоконтролем, высокими показателями локус-контроля, а также более высокой карьерной ориентацией, что говорит об их готовности к изменениям. В отличие от них педагоги, работающие в традиционной системе обучения, не хотят организовывать деятельность и пространство других, менее склонны брать ответственность на себя за результат своей работы. Не готовы к новому, склонны к проявлению беспокойства и тревоги, привязаны к уже отработанным и знакомым действиям, пессимистичны, недоверчивы, имеют высокие показатели фрустрации и ригидности, тревожности, которые вызывают оппозиционные эмоции и нежелание использовать инновации в своей деятельности [1].

Выбор инновационной деятельности над традиционной учебной деятельностью обусловлен ее содержанием, которое может детерминировать изменения в качестве педагогической направленности личности преподавателя, в т.ч. и научно-педагогического работника (табл.). professional spheres, to freedom, they are ready for new, oriented at high level of achievements in professional activity and its official recognition. They are characterized by flexibility, tolerance, emotional stability, optimism, empathy, attraction, developed emotional self-control, high indexes of locus-control and higher career orientation, which speaks for their readiness for changes. Unlike them, the teachers working in the traditional educational system don't want to organize the activity and space of others, are less oriented to take responsibility for the result of their work. They are not ready for new, are inclined for showing nervousness, worry, are attached to old and familiar actions, they are pessimistic, trustless, have high values of frustration and rigidness, worry, which evoke oppositional emotions and unwiliness to use innovations in their work [1].

The choice of innovative activity over traditional educational activity is caused by its composition, which can determine the chamges in pedagogic orientation of a teacher's personality, which includes academic employees (tab.).

Содержание инновационной и традиционной деятельности

\begin{tabular}{|c|c|c|}
\hline $\begin{array}{c}\text { Компоненты } \\
\text { содержания } \\
\text { деятельности }\end{array}$ & Инновационная деятельность & Учебная деятельность \\
\hline Определение & $\begin{array}{l}\text { Совокупность используемых мер по реа- } \\
\text { лизации инновационного процесса на раз- } \\
\text { личных уровнях образования }\end{array}$ & $\begin{array}{l}\text { Деятельность, цель которой состоит в полу- } \\
\text { чении знаний, в формировании у человека } \\
\text { умений и навыков }\end{array}$ \\
\hline Предмет & $\begin{array}{l}\text { Создает возможность самовыражения, } \\
\text { применения своих способностей, в т.ч. } \\
\text { творческих }\end{array}$ & $\begin{array}{l}\text { Усвоение знаний; } \\
\text { овладение обобщенными способами дей- } \\
\text { ствий, их алгоритмов, программ }\end{array}$ \\
\hline Средства & $\begin{array}{l}\text { Направлена на обновление системы обра- } \\
\text { зования }\end{array}$ & $\begin{array}{l}\text { Интеллектуальные действия; } \\
\text { языковые средства, в форме которых усваи- } \\
\text { вается знание; } \\
\text { фоновые знания, при условии включения в } \\
\text { них новых знаний формируется индивиду- } \\
\text { альный опыт }\end{array}$ \\
\hline Способы & $\begin{array}{l}\text { Характеризуется системностью, инте- } \\
\text { гральностью, целостностью }\end{array}$ & $\begin{array}{l}\text { Репродуктивные; } \\
\text { проблемно-творческие; } \\
\text { исследовательско-познавательные }\end{array}$ \\
\hline Продукт & $\begin{array}{l}\text { Наряду с развиваемыми умениями форми- } \\
\text { руется восприимчивость к педагогическим } \\
\text { инновациям, процесс принятия решения о } \\
\text { реализации новаций, готовность к овладе- } \\
\text { нию ими в деятельности }\end{array}$ & $\begin{array}{l}\text { Знание, лежащее в основе умения решать } \\
\text { разнообразные задачи; } \\
\text { внутреннее изменение психики и деятельно- } \\
\text { сти в эмоциональном, мотивационном, цен- } \\
\text { ностном и смысловом планах }\end{array}$ \\
\hline
\end{tabular}




\begin{tabular}{|l|l|}
\hline 1) является результатом активности чело- \\
века не столько в приспособлении к \\
внешней среде, сколько в изменении его \\
индивидуальных и общественных интере- \\
сов и потребностей; \\
2) связан с готовностью к поиску и реше- \\
нию задач за пределами внешнего кон- \\
троля: \\
внешние стимулы (материальное возна- \\
граждение, условия труда и режим работы \\
и т.д.); \\
мотивы внешнего самоутверждения (по- \\
ложительный общественный отклик на его \\
труд); \\
профессиональный мотив (желание обу- \\
чать), выражается в обращенности инно- \\
вационной деятельности обучающего на \\
обучаемых); \\
мотивы личностной самореализации \\
«быть тем, кем он может быть»)
\end{tabular} \mid

Поведение субъекта учебной деятельности - либо испытываемая им потребность продолжать эту деятельность, либо нежелание; как совокупность побудителей, включающие познавательную и коммуникативную потребность субъекта на фоне его общей потребности достижения; общее стремление учащихся к усвоению теоретических знаний направлено на овладение определенным способом решения некоторого класса частных задач

Composition of innovative and traditional activity

\begin{tabular}{|c|c|}
\hline $\begin{array}{l}\text { Components } \\
\text { of activity } \\
\text { composition }\end{array}$ & Innovative activity \\
\hline Definition & $\begin{array}{l}\text { Complex of the applied measures to imple- } \\
\text { ment innovative process at different educa- } \\
\text { tional level }\end{array}$ \\
\hline Subject & $\begin{array}{l}\text { Creates possibility to express oneself, to apply } \\
\text { own talents, including artistic ones }\end{array}$ \\
\hline Means & Aimed at justification of educational system \\
\hline Methods & $\begin{array}{l}\text { Is characterized by system character, integrity, } \\
\text { entirety }\end{array}$ \\
\hline Product & $\begin{array}{l}\text { Together with the skills, perceptivity to peda- } \\
\text { gogic innovations is formed, the process of } \\
\text { decision-making on the implementation of } \\
\text { innovations, readiness to acquire them in the } \\
\text { activity }\end{array}$ \\
\hline Result & $\begin{array}{l}\text { 1) is a result of human activity not only in } \\
\text { adaptation to the environment, but also in } \\
\text { change of his individual and social interests } \\
\text { and requirements; } \\
\text { 2) is connected to readiness for search and } \\
\text { solving the tasks outside outer control: outer } \\
\text { challenge (material reward, working condi- } \\
\text { tions and regime, etc.) } \\
\text { motives of outer self affirmation (positive } \\
\text { social response for his work); } \\
\text { professional motive (wish to teach), is ex- } \\
\text { pressed in the orientation at the students); } \\
\text { motives of self affirmation ("to be who he } \\
\text { can be") }\end{array}$ \\
\hline
\end{tabular}

Educational activity

Activity with the aim of getting knowledge, forming skills and experiences

Acquiring knowledge;

learning general ways of acting, their algorithms, programs

Intellectual actions;

language means, in the form of which knowledge is obtained;

background knowledge, with the condition of including new knowledge new experience is formed

Reproductive;

problematic-creative;

research-educational

The knowledge lying in the basis of the ability to solve various problems;

inner change of psychology and activity in emotional, motivation, axiological and sense fields

The behavior of educational activity subject his need or unwillingness to continue this activity; as a complex of stimuli, including cognitive and communicative need as part of his general need of achievements; general wish of the students to acquire theoretical knowledge is aimed at obtaining a certain method of solving some class of certain tasks 
В компонентах содержания инновационной деятельности представлен самый важный компонент развития направленности и еe результат, в т.ч. и педагогической - мотив. Осознание обучаемым ведущего мотива, собственного поведения, деятельности и необходимости его измерения является психологическим условием развития педагогической направленности личности [13].

Инновационная деятельность способствует формированию всех мотивов, но при высоком ее уровне овладения преподавателем. У педагога, активно вводящего педагогические инновации в учебный процесс, приоритетными становятся: профессиональный мотив, мотив личностной самореализации, что позволяет преподавателю стать обладателем важнейшей черты личности потребности в активном созидании. Неинтенсивная инновационная деятельность преподавателя создает условия для доминирования в структуре его личности мотивов нижних уровней - материальные мотивы, внешнего самоутверждения. Инновационное обучение участвует в развитии таких компонентов профессиональной направленности, как самовыражение, применение своих способностей, в т.ч. творческих [1].

По проблеме подготовки преподавателей, включая научно-педагогических работников, к инновационной деятельности имеются исследования:

освещен вопрос обеспечения инновационного процесса обучения студентов, показана реализация инновационных технологий обучения в рамках традиционно выстроенных учебных занятий; осуществляется подготовка к инновационной педагогической деятельности, однако это происходит слабо выражено (посредством изучения новых педагогических технологий, организации образовательной деятельности в инновационных условиях) [7, 14];

определена система психологической подготовки студентов - будущих педагогов в инновационной образовательной среде педагогического вуза [15];

подготовка преподавателя вуза происходит в системе послевузовского образования и повышения квалификации либо отдельных аспектов инновационной деятельности при обучении студентов [16-18];

реализация педагогических инноваций возможна при условии умения создавать научно-педагогическими работниками продукты
In the components of innovative activity composition the most important component of orientation development and its result is presented, including pedagogic one - the motive. Student's understanding of the leading motive, own behavior, activity and necessity of change is a psychological condition for pedagogic orientation of a personality [13].

Innovative activity helps to form all the motives, but only in case a teacher's acquirement. The teacher actively implementing pedagogical innovations into learning process has such priorities as: professional motive, motive of personality self-affirmation, which helps a teacher to obtain the most important feature - need for active creativity. Not enough intensive innovative activity of a teacher creates conditions for motives of low level domination - material motives, outer self affirmation. Innovative education takes part in the development of such professional orientation components as self-affirmation, application of own talents, including creative ones [1].

There are investigations on the problem of teachers' education, inclufing academic staff:

the question of innovative process provision for educating students is traversed, the implementation of innovative educational technologies is considered in the frames of traditionally organized lessons, preparation for innovative pedagogic activity is carried out, though it is still poorly seen (by learning new pedagogic technologies, organizing educational activity in innovative conditions) $[7,14]$;

the system of psychological preparation of students - futere teachers in innovative educational environment of a pedagogical university is defined [15];

preparation of a lecturer of a university in the system of after-university education and staff development or separate aspects of innovative activity in the process of educating students [16-18];

implementation of pedagogic innovations is possible in case of the ability of academic staff to create the products of innovative activity (technical and methodical 
инновационной деятельности (технологометодическое обеспечение технологий и приемов инновационной деятельности) [3].

Обобщая анализ инновационной деятельности по выделенной нами проблеме, считаем, что только в условиях специально созданной инновационной педагогической среды инновационная деятельность будет более эффективно детерминировать изменения в педагогической направленности личности, в т.ч. в личности научно-педагогического работника $[3,15,16]$.

Предполагаем, что условиями, усиливающими инновационную среду и позволяющими адаптироваться в ней, являются:

рефлексия обучаемых;

освоение продукта концепций ученых;

дифференцированный подход и личностная диагностика, предоставляющие возможность лично каждому участнику образовательного процесса построить индивидуальный путь обучения и развития, выбрать форму обучения и соответствующую программу;

реализация подходов к обучению инновационной деятельности: проектного, учение как исследование, общение, игровая модель, системно-деятельностного.

Попытка реализации выделенных нами условий, усиливающих инновационную среду, была совершена в рамках изучения дисциплин психолого-педагогического цикла научнопедагогическими работниками в Московском государственном строительном университете. На примере изучения инновационных технологий: проектное обучение, технология развития критического мышления через чтение и письмо, диалоговые технологии были определены основные составляющие показателей направленности научно-педагогических работников, которые могут быть показателями ее изменения:

готовности научно-педагогических работников к инновационной педагогической деятельности (выражается в умении решать педагогические задачи);

развитие способностей к инновационной деятельности;

отношение научно-педагогических работников к инновационной деятельности (методика Н.В. Матяш [19] в модификации автора);

возможности использования инноваций в педагогической деятельности;

мотивационная готовность к поиску и решению задач; support of technologies and methods of innovative activity) [3].

Generalizing the analysis of innovative activity on the considered problems we believe that only in the conditions of specially created innovative pedagogic environment the innovative activity will more efficiently determinate the changes in pedagogic orientation, including in the personality of an academic employee [3, 15, 16].

We suppose that the conditions strengthening the innovative environment and helping to adapt to it are:

reflection of the students;

acquisition of the product of scientists' concept;

differential approach and personal diagnostics, which give the possibility for each participant of educational process to choose the form of education and the corresponding program;

implementation of the approaches to innovative activity teaching: project, learning as a research, communication, game model, system-activity.

An attempt to implement the conditions detached by us, which strengthen the innovative environment, was carried out in frames of studying the disciplines of psychological and pedagogical circle by the academic staff of Moscow State University of Civil Engineering.

On the example of investigating innovative technologies: project education, technologies of critical thinking through reading and writing, dialogue technologies, the main components of orientation indicators of the academic staff were defined, which can become the indicators of its change:

the readiness of the academic staff to innovative pedagogic activity (expressed in the ability to solve the pedagogical tasks);

development of the capacities to innovative activity;

attitude of the academic staff to innovative activity (the methods of M.V. Matyash [19] in the modification of the author;

possibilities of innovations use in pedagogical activity;

motivational readiness for search and solving tasks; 
доминирование мотивов профессиональной и личностной самореализации над мотивами внешних стимулов и внешнего самоутверждения.

Bblвoдbl. Развитие педагогической направленности у научно-педагогических работников основано на исследованиях, доказывающих значимость вхождения личности в профессиональную среду.

Инновационная деятельность может быть условием развития направленности личности научно-педагогических работников.

Автором исследования сделана попытка доказательства целесообразности применения условий усиления инновационной среды в развитии направленности научно-педагогических работников.

\section{БИБЛИОГРАФИЧЕСКИЙ СПИСОК}

1. Сластенин В.А., Подымова Л.С. Педагогика: Инновационная деятельность. М. : Изд-во Магистр, 1997. 224 с.

2. Савина E.A. Затруднения в профессионально-педагогической деятельности преподавателей высшей школы // Строительство - формирование среды жизнедеятельности : сб. тр. XIV Междунар. межвуз. науч.-практ. конф. мол. уч., докт. и асп. (Москва, 27-29 апреля 2011 г.). М. : МГСУ, 2011. С. 841-844.

3. Савина E.A. Условия реализации инновационного процесса обучения специалиста инвестиционно-строительной сферы // Известия Волгоградского государственного педагогического университета. 2014. № 4 (89). С. $31-38$.

4. Основные направления политики Российской Федерации в области развития инновационной системы на период до 2010 года // АЛППП. Режим доступа: http://www.alppp.ru/law. Дата обращения: 25.11.2014.

5. Хуторской А.В. Педагогическая инноватика: методология, теория, практика. М. : Изд-во УНЦ ДО, 2005. 222 с

6. Моргун В.Ф., Ткачева Н.Ю. Проблема периодизации развития личности в психологии. М. : Изд-во МГУ, 1981. 82 с.

7. Рыбциова Л.Л. Подготовка преподавателей высшей школы в Уральском государственном университете им. А.М. Горького: традиции и инновации // Известия Уральского государственного университета. 2008. № 56. С. 7-14.

8. Фокин Ю.Г., Медведев В.Е., Попова T.B. Разработка концепции содержания базовой дисциплины психологопедагогической подготовки преподавателей технических университетов и инже(In Russian) (In Russian) (In Russian) domination of the motives of professional and personal self-fulfillment over the motives of external stimuli and external self-affirmation.

Conclusions. The development of the pedagogical orientation of the academic staff is based on the investigations, which prove the importance of inclusion of a personality to professional environment.

Innovative activity can be a condition for personality orientation development of academic staff.

The author of the work made an attempt to prove the practicability of using the conditions for strengthening the innovative environment in the development of academic staff orientation.

\section{REFERENCES}

1. Slastenin V.A., Podymova L.S. Pedagogika: Innovatsionnaya deyatel'nost' [Pedagogics: Innovative Activity]. Moscow, Magistr Publ., 1997, 224 p. (In Russian)

2. Savina E.A. Zatrudneniya $v$ professional'nopedagogicheskoy deyatel'nosti prepodavateley vysshey shkoly [Problems in Professional Pedagogic Activity of the Lecturers of Higher Schools]. Stroitel'stvo - formirovanie sredy zhiznedeyatel'nosti : sbornik trudov XIV Mezhdunarodnoy mezhvuzovskoy nauchnoprakticheskoy konferentsii molodykh uchenykh, doktorantov $i$ aspirantov (Moskva, 27-29 aprelya 2011 g.) [Construction - Forming the Living Environment : Collection of Works of the 14th International Interuniversity Science and Practive Conference of Young Scientists, Doctoral and Postgraduate Students (Moscow, April 2729, 2011). Moscow, MGSU Publ., 2011, pp. 841-844. (In Russian)

3. Savina E.A. Usloviya realizatsii innovatsionnogo protsessa obucheniya spetsialista investitsionno-stroitel'noy sfery [Conditions of Innovative Educational Process of a Specialist in Investment and Construction Activity]. Izvestiya Volgogradskogo gosudarstvennogo pedagogicheskogo universiteta [News of Volgograd State SocioPedagogical University]. 2014, no. 4 (89), pp. 31-38. (In Russian)

4. Osnovnye napravleniya politiki Rossiyskoy Federatsii v oblasti razvitiya innovatsionnoy sistemy na period do 2010 goda [Main Directions of Russian Federation Policy in the Field of Innovative System Development for the Period up to 2010]. ALPPP. Available at: http://www.alppp.ru/law. Date of access: 25.11.2014. (In Russian)

5. Khutorskoy A.V. Pedagogicheskaya innovatika: metodologiya, teoriya, praktika [Pedagogical Innovation Studies: Methodology, Theory, Practice]. Moscow, UNTs DO Publ., 2005, 222 p.

6. Morgun V.F., Tkacheva N.Yu. Problema periodizatsii razvitiya lichnosti v psikhologii [Periodization Problem of Personality Development in Psychology]. Moscow, MGU Publ., 1981, 82 p.

7. Rybtsova L.L. Podgotovka prepodavateley vysshey shkoly v Ural'skom gosudarstvennom universitete im. A.M. Gor'kogo: traditsii i innovatsii [Education of the Teachers for Higher Schools in Ural Federal University Named after A.M. Gorgy: Traditions and Innovations]. Izvestiya Ural'skogo gosudarstvennogo universiteta [News of Ural Federal University]. 2008, no. 56, pp. 7-14. 
нерных вузов // Итоговый отчет по гранту 97-28-1.7-130, выделенному Министерством общего и профессионального образования РФ для исследований в области педагогики. М., 2000.

9. Ломов Б.Ф. Вопросы общей, педагогической и инженерной психологии. М. : Педагогика, 1991. 296 с.

10. Зеер Э.Ф., Зборовский Г.Е., Соломина Г.М. Социально-психологические особенности личности инженера-педагога : сб. науч. тр. Свердловск : Изд-во СИПИ, 1988. $107 \mathrm{c}$.

11. Парамзин В. Профессиональная направленность личности и ее формирование в школьные годы. Новосибирск : Кн. изд-во, $1987.153 \mathrm{c.}$

12. Маралов В.Г., Апуневич О.А., Кудака М.А., Маралова Т.П., ва О.В., Першина Т.В., Перченко Е.Л., Поникарова В.Н., Сборчева Т.В., Шишова А.В. Психологическая коррекция как фактор обеспечения безопасности развития личности / под ред. В.Г. Маралова. Череповец : ФГБОУ ВПО ЧГУ, 2011. 336 с.

13. Митина Л.М. Психология труда и профессионального развития учителя. М. : Академия, 2004. 320 с.

14. Сорокопуд Ю.В. Повышение эффективности системы подготовки преподавателей высшей школы: пути и решения: монография. М. : ВУ, 2010. 170 с.

15. Зобнина Т.В. Концепция психологической подготовки студентов-педагогов на основе акмеологического подхода // Акмеология. 2011. № 3. С. 117-120.

16. Гришин А.В., Кустов Л.М. Проблема актуализации социально-педагогической инициативы специалистов профессиональной школы: монография. Челябинск : Акме-Проф, 1999. 110 с.

17. Назарова Л.И. Актуальные проблемы педагогической инноватики // Актуальные вопросы подготовки специалистов сельскохозяйственного производства : сб. науч. тр. М. : МГАУ им. В.П. Горячкина, 1998. C. $30-35$.

18. Якушева Л.М. Инновационная деятельность преподавателя высшей школы как средство повышения квалификации преподавательского состава // Современные наукоемкие технологии. 2011. № 1. C. $130-131$.

19. Матяш Н.В. Психология проектной деятельности школьников в условиях технологического образования / под ред. В.В. Рубцова. Мозырь : РИФ «Белый ветер», 2000. 286 c.

Поступила в редакцию в декабре 2014 г.
8. Fokin Yu.G., Medvedev V.E., Popova T.V. Razrabotka kontseptsii soderzhaniya bazovoy distsipliny psikhologopedagogicheskoy podgotovki prepodavateley tekhnicheskikh universitetov i inzhenernykh vuzov [Development of the Concept of Basic Discipline Composition of Psychological and Pedagogical Education of the Teachers of Technical and Engineering Universities]. Itogovyy otchet po grantu 97-28-1.7-130, vydelennomu Ministerstvom obshchego i professional'nogo obrazovaniya $R F$ dlya issledovaniy $v$ oblasti pedagogiki [Final Report on Grant 97-28-1.7-130 given by the Ministry if General and Professional Education of the RF for Research in Pedagocics]. Moscow, 2000. (In Russian)

9. Lomov B.F. Voprosy obshchey, pedagogicheskoy $i$ inzhenernoy psikhologii [Questions of General, Pedagogic and Engineering Psychology]. Moscow, Pedagogika Publ., 1991, 296 p. (In Russian)

10. Zeer E.F., Zborovskiy G.E., Solomina G.M. Sotsial'nopsikhologicheskie osobennosti lichnosti inzhenera-pedagoga : sbornik nauchnykh trudov [Social and Psychological Features of a Personality of a Teacher-Engineer : Collection of Scientific Works]. Sverdlovsk, SIPI Publ., 1988, 107 p. (In Russian)

11. Paramzin V. Professional'naya napravlennost' lichnosti $i$ ee formirovanie $v$ shkol'nye gody [Professional Orientation of a Personality and its Formation in School Years]. Novosibirsk, Knizhnoe izdatel'stvo Publ., 1987, 153 p. (In Russian)

12. Maralov V.G., Apunevich O.A., Kudaka M.A., Maralova T.P., Nifontova O.V., Pershina T.V., Perchenko E.L., Ponikarova V.N., Sbortseva T.V., Shishova A.V. Psikhologicheskaya korrektsiya kak faktor obespecheniya bezopasnosti razvitiya lichnosti [Psychological Correction as a Factor for Personality Development Safety Provision]. Under editorship of V.G. Maralov. Cherepovets, FGBOU VPO ChGU Publ., 2011, 336 p. (In Russian)

13. Mitina L.M. Psikhologiya truda i professional'nogo razvitiya uchitelya [Psychology of the Work and Professional Development of a Teacher]. Moscow, Akademiya Publ., 2004, 320 p.

14. Sorokopud Yu.V. Povyshenie effektivnosti sistemy podgotovki prepodavateley vysshey shkoly: puti i resheniya: monografiya [Raising the Efficiency of Teachers' Education Efficiency of a Higher School: Ways and Solutions: Monograph]. Moscow, VU Publ., 2010, 170 p. (In Russian)

15. Zobnina T.V. Kontseptsiya psikhologicheskoy podgotovki studentov-pedagogov na osnove akmeologicheskogo podkhoda [Concept of Psychological Education of the Students-Pedagogues Basing on Acmeological Approach]. Akmeologiya [Acmeology]. 2011, no. 3, pp. 117-120. (In Russian)

16. Grishin A.V., Kustov L.M. Problema aktualizatsii sotsial'no-pedagogicheskoy initsiativy spetsialistov professional'noy shkoly: monografiya [Problems of Social Pedagogic Initiative Actualization of the Specialists of Professional School: Monograph]. Chelyabinsk, Akme-Prof Publ., 1999, 110 p. (In Russian)

17. Nazarova L.I. Aktual'nye problemy pedagogicheskoy innovatiki [Current Problems of Pedagogic Innovative Studies]. Aktual'nye voprosy podgotovki spetsialistov sel'skokhozyaystvennogo proizvodstva : sbornik nauchnykh trudov [Current Issues of Educating the Specialists in Agricultural Production : Collection of Scientific Articles]. Moscow, MGAU im. V.P. Goryachkina Publ., 1998, pp. 30-35. (In Russian)

18. Yakusheva L.M. Innovatsionnaya deyatel'nost' prepodavatelya vysshey shkoly kak sredstvo povysheniya kvalifikatsii prepodavatel'skogo sostava [Innovative Activity of a Teacher of Higher School as a Means of Academic Staff Improvement]. Sovremennye naukoemkie tekhnologi. [Modern High Technologies]. 2011, no. 1, pp. 130-131. (In Russian) 
19. Matyash N.V. Psikhologiya proektnoy deyatel'nosti shkol'nikov $v$ usloviyakh tekhnologicheskogo obrazovaniya [Psychology of Project Activities of Pupils in the Conditions of Technological Education]. Under editorship of V.V. Rubtsov. Mozyr, RIF «Belyy veter» Publ., 2000, 286 p. (In Russian)

Received in December 2014.

О б а в т о р е : Савина Екатерина Александровна кандидат психологических наук, доцент, доцент кафедры социальных, психологических и правовых коммуникаций, Московский государственный строительный университет (ФГБОУ ВПО «МГСУ»), 129337, г. Москва, Ярославское шоссе, д. 26, katerina_as@ mail.ru.
A b o u t th e a u th o r: Savina Ekaterina Aleksandrovna Candidate of Psychological Sciences, Associate Professor, Department of Social, Psychological and Juristic Communications, Moscow State University of Civil Engineering (MGSU), 26 Yaroslavskoe shosse, Moscow, 129337, Russian Federation; katerina_as@mail.ru.

\section{Для цитирования:}

Савина E.A. Инновационная деятельность как условие развития профессиональной направленности личности научно-педагогических работников инвестиционно-строительной сферы // Строительство: наука и образование. 2014 . № 4. Ст. 5. Режим доступа: http://www.nso-journal.ru.

For citation:

Savina E.A. Innovatsionnaya deyatel'nost' kak uslovie razvitiya professional'noy napravlennosti lichnosti nauchnopedagogicheskikh rabotnikov investitsionno-stroitel'noy sfery[Innovative Activity as a Development Condition for Professional Orientation of a Personality of Academic Employee in Investment and Construction Sphere]. Stroitel'stvo: nauka i obrazovanie [Construction: Science and Education]. 2014, no. 4, paper 5. Available at: http://www.nso-journal.ru. (In Russian) 